\title{
Seed predation by rodents and safe sites for large-seeded trees in a fragment of the Brazilian Atlantic forest
}

\author{
Pinto, SRR., Santos, AMM. and Tabarelli, M.* \\ Departamento de Botânica, Universidade Federal de Pernambuco, \\ Rua Moraes Rego, s/n, CDU, CEP 50670-901, Recife, PE, Brazil \\ *e-mail: mtrelli@ufpe.br \\ Received July 31, 2007 - Accepted November 12, 2007 - Distributed August 31, 2009
}

(With 4 figures)

\begin{abstract}
Seed predation by small rodents is an emerging theme in the ecology of modified landscapes. Here we investigate the role played by the small rodent Oryzomys oniscus as a seed predator of large-seeded trees in a large remnant of the Atlantic forest - the Coimbra forest (3,500 ha), Alagoas state, northeastern Brazil. O. oniscus was captured and identified by setting twenty $500 \mathrm{~m}$ long transects, each one composed of 25 traps $20 \mathrm{~m}$ apart. This procedure resulted in 483 trap-nights set during a 20-mo period. We used 692 seeds (>15 mm length) from ten local large-seeded tree species for the seed predation trials that basically consisted of three treatments: one seed on the ground freely accessed by vertebrates (unprotected seed), one seed totally protected by an exclosure, and one partially-protected seed (exclosure just for medium-sized and large vertebrates). O. oniscus was captured throughout the Coimbra forest including forest edges (76 captures) and interior areas (67), and this small rodent was responsible for all seed predation visually documented inside exclosures. A 24 hours period of seed exposition permitted elevated rates of seed removal and predation. Seeds were much more removed/predated beneath fruiting trees, but rates varied according to the level of seed protection $-26.3 \%$ of predation among partially-protected versus $19.2 \%$ among unprotected seeds. Seeds suffered higher levels of seed predation/removal at the forest edge as well (up to 90\%). In both habitats, most seeds ( $>84 \%)$ remained intact beneath trees without fruits, regardless of the level of seed protection. Our results suggest that $O$. oniscus may operate as an effective large-seed predator in forest fragments, in which adult trees without fruits constitute low resource spots and thereby provide, at least temporarily, safe sites for large seeds.
\end{abstract}

Keywords: frugivory, Janzen-Connell model, Oryzomys oniscus, seed dispersal, tropical forest.

\section{Predação de sementes por roedores e sítios seguros para árvores com grandes sementes em um fragmento de floresta Atlântica brasileira}

\section{Resumo}

Predação de sementes por pequenos roedores é um tema emergente na ecologia de paisagens modificadas. Nesse estudo foi investigado o papel desempenhado pelo pequeno roedor Oryzomys oniscus como predador de grandes sementes de árvores em um grande fragmento de floresta Atlântica - mata de Coimbra (3.500 ha), Estado de Alagoas, Nordeste do Brasil. O. oniscus foi capturado e identificado usando-se 20 transectos com $500 \mathrm{~m}$ de comprimento, cada um composto por 25 armadilhas espaçadas a cada $20 \mathrm{~m}$. Esse procedimento resultou em um esforço total de captura de 483 armadilhas-noites, durante um período de 20 meses. Foram utilizadas 692 grandes sementes (>15 mm de comprimento), provenientes de dez espécies de árvores para as sessões de predação, as quais consistiram basicamente de três tratamentos: uma semente no solo com acesso livre para vertebrados (semente desprotegida), uma semente totalmente protegida e uma semente parcialmente protegida (exclusão apenas para médios e grandes vertebrados). O. oniscus foi capturado em todo o fragmento de Coimbra, incluindo bordas de floresta (76 capturas) e áreas de interior (67 capturas). Além disso, esse pequeno roedor foi responsável por toda a predação de sementes visualmente documentada dentro das gaiolas de proteção de sementes. Um período de 24 horas de exposição das sementes permitiu elevadas taxas de remoção e predação. Sementes foram muito mais predadas/removidas debaixo de árvores frutificando, mas as taxas variaram de acordo com o nível de proteção das sementes - 26,3\% de predação entre as parcialmente protegidas versus $19,2 \%$ entre sementes não protegidas. Sementes sofreram altos níveis de predação/ remoção nas bordas de florestas (até 90\%). Em ambos os hábitats, muitas sementes (>84\%) permaneceram intactas debaixo de árvores sem frutos, independente do nível de proteção. Os resultados do estudo sugerem que $O$. oniscus 
pode agir como um predador efetivo de grandes sementes em fragmentos de floresta. Árvores adultas, sem a presença de frutos, parecem constituir locais de baixa disponibilidade de recurso e, portanto, podem prover, pelo menos temporariamente, sítios seguros para grandes sementes.

Palavras-chave: dispersão de sementes, floresta tropical, frugivoria, modelo Janzen-Connell, Oryzomys oniscus.

\section{Introduction}

Successful seedling recruitment represents a bottleneck for tropical trees (Whitmore, 1996) and recruitment greatly benefits from effective seed dispersal (Janzen, 1970; Levey et al., 2002; Forget and Janzen, 2007). Briefly, seed dispersal represents seed removal and discarding away from parental plants (Terborgh, 1990) and, in fact, it has been recognised as one of the most important factors affecting plant recruitment, spatial distribution, and long term persistence of plant populations (Terborgh and Nuñez-Iturri, 2006; Nuñez-Iturri and Howe, 2007). Benefits of seed dispersal include reduced seed predation and seedling mortality - escape hypothesis sensu Howe and Smallwood (1982); colonisation of new habitats (Redford, 1992; Corlett and Turner, 1997); seed release from fruits (Asquith et al., 1997); seed discarding in microhabitats suitable for seed germination (Howe and Smallwood, 1982; Hoch and Adler, 1997); seed burial (Forget, 1990); and enhanced seed-mediated gene flow (Jordano et al., 2007). A classic example from a Neotropical forest tree is the strict dependence of Bertholletia excelsa large-seeds, which must be released from an extremely hard pixidium and buried by agoutis in order to have higher chances of germination and successful recruitment (see Peres et al., 1997).

The escape hypothesis derives greatly from the Janzen-Connell model (Janzen, 1970; Connell, 1971), which correlates the rate of recruitment of tropical trees with distance from parents. Seeds and seedlings beneath or close to parents usually achieve higher densities and consequently they are more susceptible to predators and pathogens that respond positively to resource spatial aggregation (Janzen, 1970; 1971). In fact, escape from predation and mortality beneath parents has been proposed as the main selective force leading to the emergence of a large array of adaptations for seed dispersal among tropical trees, including devices that permit seed dispersal by abiotic vectors (such as wind and water) or mediated by animals such as ants, bats, birds, rodents and monkeys (Whitmore, 1991; Richards, 1996). However, plant recruitment does not exclusively result from mortality driven by density-dependent factors, as recruitment is expected to occur where seed/seedling face suitable conditions in terms of soil nutrients, water supply and light availability as well (Turner, 2001).

This "ideal place" for recruitment has been referred to in the literature as safe sites (sensu Harper, 1994), and in the case of tropical large-seeded trees (seeds $\geq 1.5 \mathrm{~cm}$ length), it is expected to occur where seeds escape the immense predation pressure driven by a myriad of species. Large seeds can contain high levels of protein, lipids and/or carbohydrates and because of this they represent an import nutrient source in the diet of insects, such as bruchid beetles (e.g., Caryobruchus, Pachymerus, Speciomerus species), which have in the large seeds a crucial resource for larval development and are able to impact crops and plant fitness (Wilson and Janzen, 1972; Henderson, 2002). But vertebrates represent a pervasive source of tree seed predation as well (Asquith et al., 1997; Wright and Duber, 2001). In the Neotropical forests, a plethora of primate species (Cintra and Horna, 1997), birds (Reis, 1995), ungulates (Kiltie, 1981; Fragoso, 1998) and rodents (Smythe, 1989; Silva and Tabarelli, 2001) feed on tree seeds. Rodents are the most diverse group of terrestrial mammals in neotropical forests (Guimarães et al., 2005) and particularly the medium-bodied, scatter-hoarding species (Proechimys, Sciurus, Dasyprocta) appear to play an essential role as both seed predators and dispersers of medium- and large-seeded trees (DeMattia et al., 2004; Pimentel and Tabarelli, 2004; Fleury and Galetti, 2006; Galetti et al., 2006).

However, several studies have provided both experimental and empirical evidence that even small rodents ( $<150$ g, e.g., Heteromys, Oryzomys, Oecomys, Rhipidomys species) may represent an expressive source of seed predation, including large seeds (Adler, 1995; DeMattia et al., 2004). It is particularly true for heavily defaunated forest fragments or predator-free patches with their distorted vertebrate communities in which small rodents tend to be overabundant (see Terborgh et al., 2001; Dirzo and Mendoza, 2007; Lopez and Terborgh, 2007). Currently, the role played by small rodent communities as seed predators remains neglected (i.e., few studies); and unclear since rodent abundance, as well as rates of seed harvesting, dispersal and predation by rodents are greatly affected by a myriad of factors such as seed size (Lopez and Terborgh, 2007), fruit pulp availability (Guimarães et al., 2005) nest site availability (Briani et al., 2001), habitat features (Talamoni and Dias, 1999; Fleury and Galetti, 2006), season (DeMattia et al., 2004), abundance of rodent predators (Dirzo and Mendoza, 2007), patch size and hunting pressure (Galetti et al., 2006). Here we investigate the role played by the small rodent Oryzomys oniscus as a large-seed predator in a remnant of the Atlantic forest, northeast Brazil. First, we present capture rates for this small rodent within different forest habitats. Secondly, rates of seed predation for ten largeseeded tree species are offered and we analyse variation 
on seed fate in response to habitat, resource availability and level of seed protection. Finally, we address possible implications for the uncovered patterns in terms of safe sites for large-seeded trees.

\section{Material and Methods}

\subsection{Study site}

The study was carried out in a 3,500 ha, Atlantic forest fragment (the Coimbra forest) at Usina Serra Grande, a large, private sugar company located in the State of Alagoas, northeastern Brazil ( $8^{\circ} 30^{\prime} \mathrm{S}$ and $35^{\circ} 50^{\prime} \mathrm{W}$; Figure 1). The Serra Grande landscape is located on a low-altitude plateau (300-400 m above sea level) containing two similar classes of dystrophic soils with high clay fractions: yellow-red latosols and yellow-red podzols, according to the Brazilian soil classification system (IBGE, 1985). Annual rainfall is $~ 2,000 \mathrm{~mm}$, with a 3-month dry season ( $<60 \mathrm{~mm} / \mathrm{month})$ from November to January. The predominantly lowland terra firme forest included two physiognomic subtypes: evergreen and semi-deciduous forests (Veloso et al., 1991). On a regional scale, the Leguminosae, Lauraceae, Sapotaceae, Chrysobalanaceae and Lecythidaceae account for most tree species (Grillo et al., 2006).

The Coimbra forest is the largest and best preserved forest patch in the region. Coimbra still retains

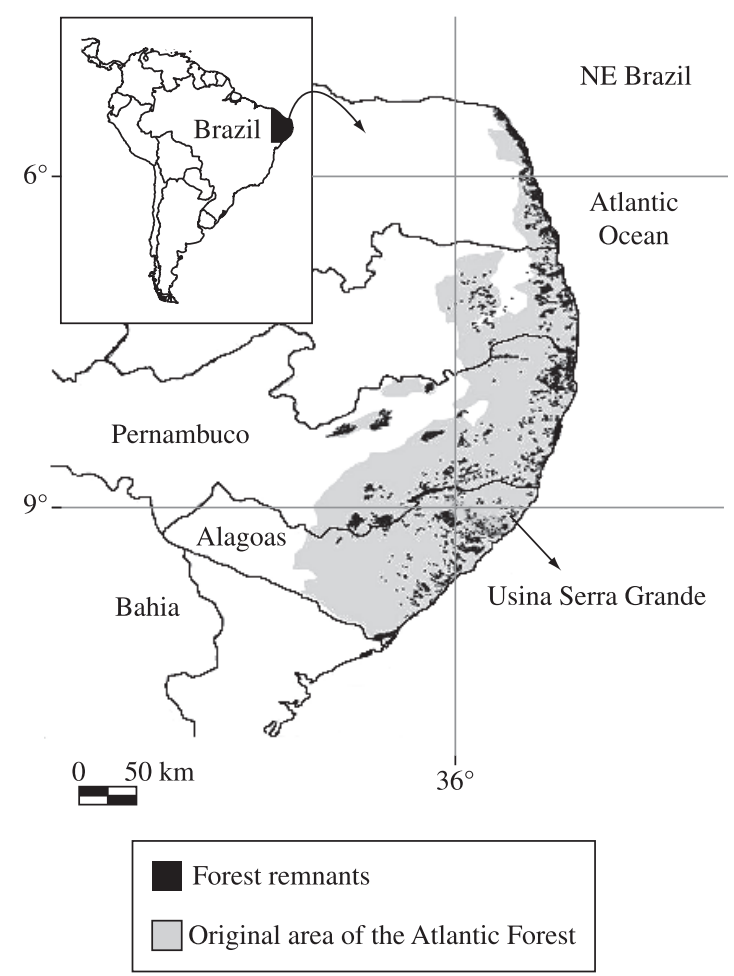

Figure 1. Location of the Coimbra forest, Usina Serra Grande, Brazil. a full complement of plants typical of vast undisturbed tracts of Atlantic forest, such as large-seeded trees (Silva and Tabarelli, 2000; Tabarelli and Peres, 2002). Additionally, it houses residual populations of smalland medium-sized vertebrates that act as both seed dispersers and predators (e.g., Oryzomys oniscus, Oecomys concolor, Sciurus aestuans, Agouti paca, Dasyprocta prymnolopha, Didelphis albiventris), but lack larger species e.g., Tapirus terrestris, Tayassu species and the howler monkey Alouatta belzebul (Fernandes, 2003; Pimental and Tabarelli, 2004). Pôrto et al. (2006) offer a comprehensive list of trees, mammals and bird species inhabiting the Serra Grande landscape.

\subsection{Oryzomys oniscus}

Oryzomys oniscus Thomas, 1904 (Muridae) has been recorded in the Atlantic forest region and it is locally and popularly called "forest rat" (Oliveira and Langguth, 2004). The genus Oryzomys ranges from the southeastern United States through Central and South America to northern Chile and Argentina. Species within this genus are highly variable in size, color, and tail length, but adults generally weigh $<150 \mathrm{~g}$ (Eisenberg and Redford, 1999). Oryzomys species inhabiting tropical forests usually live on the ground (see Briani et al., 2001; Grelle, 2003), where they feed on seeds (mainly small seeds), fruit pulp, arthropods and arbuscular fungi (Mangan and Adler, 2000; Bergallo and Magnusson, 2002; Vieira et al., 2003). The small-bodied Oryzomys species are more specialised in their seed consumption and are mainly seed eaters instead of seed dispersers (see Henry, 1997; DeMattia et al., 2004). O. oniscus recorded on the Coimbra forest was identified by Dr. Alfredo Langguth and some specimens are available in the mammal collection of the Universidade Federal da Paraíba (UFPB vouchers no. 5247, 5248).

\subsection{Rodents and seed predation trials}

In order to confirm that $O$. oniscus is the main small rodent living on the ground of Coimbra forest, we set twenty $500 \mathrm{~m}$ long transects, which were composed of 25 traps $20 \mathrm{~m}$ apart. Traps consisted of wire cages $15 \times 15 \times 25 \mathrm{~cm}$ (mash net $10 \mathrm{~mm}$ of aperture), and we used a mix of ripe fruits (banana and pineapple) as bait. Transects started in the first metre of forest vegetation, perpendicular to the margin of the fragment, and penetrated $500 \mathrm{~m}$ into forest. Transects were set haphazardly, preserving a minimum between-transect distance of $50 \mathrm{~m}$, one per night and remained in the field from 6:00 PM to 6:00 AM (a 12 hours period of capture). This procedure totalised a capture effort of 483 trap-nights during a 20-mo period (January 2003/October 2004). The nearest tree $(\mathrm{DBH} \geq 10 \mathrm{~cm})$ of each trap was assigned as a fruiting or a non-reproductive tree. By these procedures, we did not intend to estimate any rodent population attribute (e.g., rodent density) as it would require a capture-recapture effort beyond our operational possibilities. 
Seed removal and predation was investigated based on ten large-seeded tree species (seeds 15-110 mm length) as follows: Attalea oleifera (Palmae), Byrsonima stipulacea (Malpighiaceae), Cordia nodosa (Boraginaceae), Euterpe edulis (Palmae), Virola gardneri (Myristicaceae), Hymenaea courbaril (Leguminosae), Lecythis lurida and Lecythis pisonis (Lecythidaceae), Tovomita mangle (Clusiaceae) and Licania kunthiana (Chrysobalanaceae). Voucher specimens are available at UFP Herbarium, Universidade Federal de Pernambuco (Serra Grande collection, vouchers $\left.n^{\circ} 34,445-38,904\right)$. This set of species was selected in order to cover a large range of seed size within the group of the large-seeded tree species, as both fruit and seed size largely influence the assemblage of species operating as dispersers/predators (Howe and Smallwood, 1982; Turner, 2001).

Seed fate trials consisted of three basic treatments disposed on the ground: 1) protected seed - one intact, fresh seed totally protected by a vertebrate exclosure (wire cages $8 \times 8 \times 8 \mathrm{~cm}$; mash net $10 \mathrm{~mm}$ of aperture); 2) partially-protected seed - one intact, fresh seed partially protected by a vertebrate exclosure with a single small aperture of $25 \mathrm{~cm}^{2}$ in order to permit seed access by small rodents; and 3) unprotected seed - one intact, fresh seed with free access to any vertebrate species.

Each seed fate trial consisted of these three treatments, which were disposed $5 \mathrm{~m}$ apart beneath the crown of an adult tree from any of the ten seed species addressed in this study (i.e., a trial = three seeds beneath one adult tree). Adult trees included both fruiting individuals and individuals without fruit. By this procedure we guaranteed that all sets of seed species had seeds exposed beneath adults of their own species as well as beneath adults from the other species used in the study. Trials were repeated at least 20 times for each seed species by using different and independent adult trees (at least $50 \mathrm{~m}$ apart); which totalised 692 exposed seeds (plus one seed discarded further due to injury) beneath 231 adult trees in the whole experiment. Trials were always set haphazardly in the Coimbra forest at 6:00 AM and checked after 24 hours, and at the end of this period, seeds were assigned within one of three categories of seed fate: still intact, predated (i.e., partially or totally eaten) or removed (i.e., disappeared). Trials were conducted at the forest edge $(\leq 100 \mathrm{~m})$ and forest interior $(>100 \mathrm{~m})$.

Seed fate trials were carried out during eight months, from March 2004 up to October 2004 in order to guarantee independence among seed trials. March to October usually covers the rainy season in the study region (IBGE, 1985), and this trial period corresponded, partially or completely, to the fruiting season of the seed species addressed; we always used fresh and intact seeds for treatments. Finally, in order to record vertebrate species acting as seed predators on seed trials, we spent over 120 hours of focal observation, including observations for the complete set of seed species addressed in the study. Seed trials were monitored early in the morning, at dusk and at night (by using binoculars), with observers positioned 10 to $15 \mathrm{~m}$ from adult trees (see Tabarelli and Pimentel, 2004). We previously collected and taxidermied $O$. oniscus specimens to facilitate visual identification on seed trials.

\subsection{Data analysis}

Differences on the proportion of rodent captures and seeds within categories of seed fate were analysed by $\mathrm{G}$ tests (Sokal and Rohlf, 1995). In order to identify the factors driving seed predation and removal, we run a log-linear model using habitat (edge and interior forest), resource availability (fruiting trees and trees without fruit), and level of seed protection (protected, partially protected, unprotected) as factors to explain seed fate, which consisted of three mutually exclusive categories: predated, removed and intact. The initial model consisted of a saturated or complete model with all main effects and interactions. The most parsimonious model was then achieved after successive exclusions of no-significant terms. The final model consisted of the minimal fitted model with only significant interactions as proposed by Sokal and Rohlf (1995).

\section{Results}

O. oniscus was captured throughout the Coimbra forest including forest edges (76 captures, 29\% of capture success) and interior areas (67 captures, 30.3\%). However, this rodent was much more captured close or beneath fruiting trees $-45 \%$ (55 captures from 118 efforts) versus $25 \%(88 / 365)$ close to trees without fruits $(\mathrm{G}=20.59$, d.f. $=1, \mathrm{p}<0.001)$. Traps also captured a small number of common opossums (Didelphis albiventris). A 24 hours period of seed exposition permitted elevated rates of seed removal and predation among partiallyprotected and unprotected seeds. Roughly, $50 \%$ of those seeds were either removed or predated regardless of their taxonomic identity, and protected seeds remained practically intact despite the fact that few of these seeds were predated or removed after vertebrates destroyed the exclosures. Precisely, seed predation by any vertebrate (unprotected seeds, Figure 2a) varied from 3.5\% (L. lurida) to $13.6 \%$ (V. gardneri), whereas predation by small rodents (partially-protected seeds, Figure $2 b$ ) varied between $4.7 \%$ ( $H$. courbaril) and $26.6 \%$ (L. lurida). These figures represented an elevated rate of predation for a 24-hour period of seed exposition, and during the 120 hours of focal observation, only O. oniscus was visually recorded as a seed predator (as rodents consumed seeds partially or completely), including seed predation within the exclosures for medium-sized and large vertebrates (i.e., partially-protected seeds). Seed dispersal by $O$. oniscus was not visually recorded.

The log-linear model revealed significant contributions of habitat, resource availability and seed protection on the seed fate, including several interactions among factors (Table 1). Seeds were much more removed and predated beneath fruiting trees (Figure 3), but rates varied 

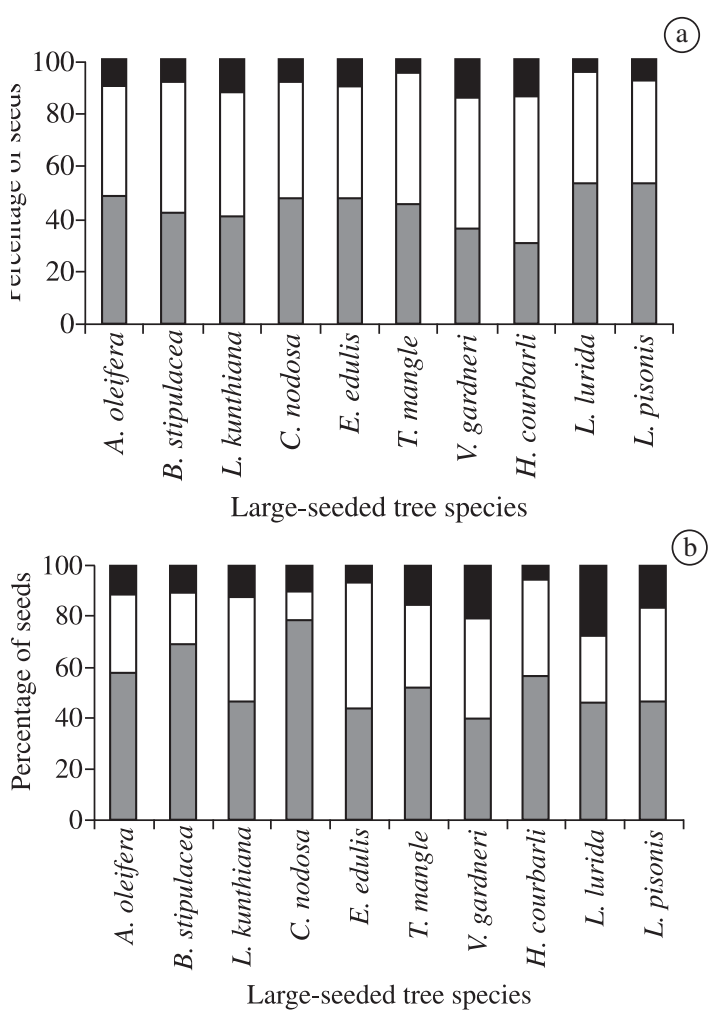

Predated $\square$ Removed $\square$ Intact

Figure 2. Percentage of a) unprotected seeds, and b) partially-protected seeds from 10 large-seeded tree species within categories of seed fate in the Coimbra forest, Brazil

Table 1. Factors and interactions of a log-linear model fitted to the number of large seeds, from a set of ten tree species, within three categories of seed fate (intact, removed and predated) at Serra Grande, Brazil ( $\mathrm{n}=692$ seeds).

\begin{tabular}{lcrc}
\hline Factors and interactions & d.f. & \multicolumn{1}{c}{$\chi^{2}$} & p \\
\hline Habitat & 1 & 4.89 & 0.027 \\
Resource availability & 1 & 3.11 & 0.077 \\
Seed protectionw & 2 & 22.83 & $<0.0001$ \\
Seed fate & 2 & 81.96 & $<0.0001$ \\
Habitat*resource & 1 & 8.66 & 0.0033 \\
availability & & & \\
Habitat*seed fate & 2 & 6.54 & 0.037 \\
$\begin{array}{l}\text { Resource availability } \\
\text { *seed fate }\end{array}$ & 2 & 56.65 & $<0.0001$ \\
Seed protection*seed fate & 4 & 157.69 & $<0.0001$ \\
$\begin{array}{l}\text { Resource*protection } \\
\text { *seed fate }\end{array}$ & 4 & 34.74 & $<0.0001$ \\
Habitat*resource*seed fate & 2 & 7.49 & 0.023 \\
\hline
\end{tabular}

according to the level of seed protection - seed predation reached $26.3 \%$ among those partially-protected versus $19.2 \%$ of those unprotected. Moreover, a large proportion of partially protected $(87 \%)$ and unprotected seeds

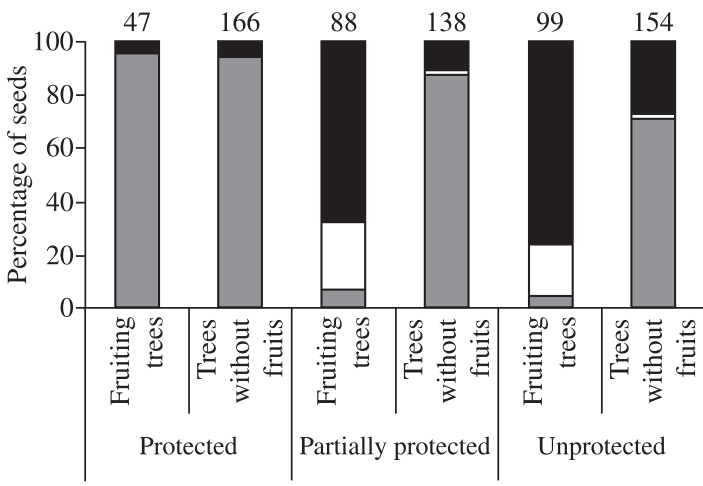

$\square$ Predated $\square$ Removed $\square$ Intact

Figure 3. Percentage of seeds within categories of seed protection, resource availability and fate in the Coimbra forest, Brazil ( $n=692$ seeds from 10 large-seeded tree species). Some protected seeds were removed after exclosure destruction by nocturnal mammals. See Table 1 for the log-linear model fitted to the number of seeds within three categories of seed fate.

(71\%) remained intact after a 24 hours of exposition beneath trees without fruits. Seeds suffered higher levels of seed predation/removal at the forest edge (up to 90\%), and rates were higher beneath fruiting trees (Figure 4). In both habitats, most seeds $(>84 \%)$ remained intact beneath trees without fruits, regardless of the level of seed protection, and few seeds were effectively predated.

\section{Discussion}

Our results suggest that large-seeded tree species face elevated rates of seed predation in the Coimbra forest, particularly on forest edges, as $25 \%$ of all seeds beneath fruiting trees in this habitat were predated within a 24 hours period of seed exposition- overall $90 \%$ of them were predated or removed in this extremely short period. The small rodent $O$. oniscus appears to represent a substantial source of predation for large seeds in the aftermath of seed disposal on the ground as we did not visually record other species predating seeds inside the exclosures (partially-protected seeds), as well as those unprotected. Moreover, O. oniscus was recorded at all transects and fed on seeds from all species addressed in the experiment, except the very hard pyrenes of A. oleifera (just pulp consumption). These findings suggest that this rodent is abundant, at least in certain periods of time, and a generalist large-seed predator in the Coimbra forest. Finally, we documented a relatively low rate of seed predation and removal beneath the crowns of trees without fruits $(<30 \%)$. Apparently, foraging activity by seed predators is focused on fruiting trees (as indicated by rodent capture) and seeds spatially concentrated on the ground (i.e., high levels of resource availability). It implies that large seeds discarded around nonreproductive trees face a lower chance of being predated 


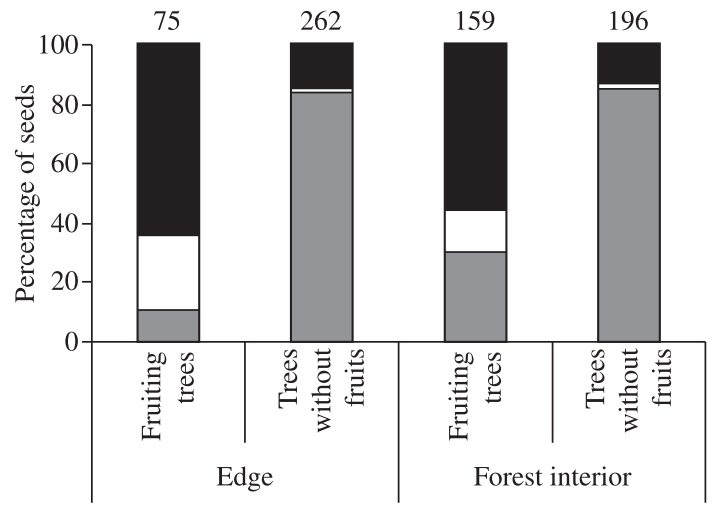

Habitat and resource availability

$\square$ Predated $\square$ Removed $\square$ Intact

Figure 4. Percentage of seeds within categories of habitat, resource availability and fate in the Coimbra forest, Brazil ( $n=692$ seeds from 10 large-seeded tree species). See Table 1 for the log-linear model fitted to the number of seeds within three categories of seed fate.

and consequently, such areas consist of safe sites for the recruitment of large-seeded trees.

Our findings, however, do not exclude the possibility that other rodent species are operating as active seed predators at the study site as previously documented by Pimentel and Tabarelli (2004) for Attalea oleifera large seeds. Many seeds that disappeared from seed trials may have been completely consumed while we were not visually monitoring the experiment. Currently, there is a great debate about the process affecting long-term persistence of tree species in fragmented forest landscapes, including seed predation by rodents (see Fleury and Galetti, 2006; Santos et al., 2008). Several studies have proposed that small rodents and leaf-cutting ants tend to suffer ecological release in small forest patches as their predators become extinct in response to habitat loss (Terborgh et al., 2001). Additionally, large and medium-sized vertebrates that act as both seed predators and dispersers are eliminated at local and landscape level by over-hunting (Wright, 2003; Jordano et al., 2006; Wright et al., 2007). Greatly elevated densities of small rodents and lack of some medium-to-large-bodied mammals originate distorted vertebrate communities that may produce tangible impacts on plant recruitment. Empirical and experimental evidence from tropical forests in Central America suggest that small rodents prey preferentially on small seeds and it has been proposed to be the process driving abundant recruitment of large-seed trees in Los Tuxtlas, despite the hyper-abundance of the small rodent Heteromys desmarestianus (Dirzo and Mendoza, 2007). Conversely, Lopez and Terborgh (2007) did not detect disrupted seed removal/predation by overabundant rodents on predator-free artificial islands. These authors argued that seedling herbivory by leaf-cutting ants may exceed the negative impact promoted by rodents regarding seed predation and plant recruitment.

Our study did not intend to address a possible ecological release of small rodents in the Coimbra forest but we were able to document rapid and elevated rates of large-seed predation and removal. In fact, $O$. oniscus was able to prey a significant number of large seeds beneath several tree species despite any preference in terms of seed size. Similar findings have been reported elsewhere. $O$. talamancae, for instance, was identified as one of the most important seed predators for 11 tree species in a tropical forest site in Costa Rica (Corcovado National Park), including ten large-seeded species (DeMattia et al., 2004). For some tree species, such as Virola koshnyi (seeds $17.8 \pm 1.57 \mathrm{~mm}$ length), predation by small rodents represented over $70 \%$ of the seeds destroyed in the seedpredation trials. Moreover, $O$. talamancae was by far the most abundant small rodent species; namely it reached over 150 individuals per hectare in particular months. Another finding by DeMattia et al. (2004) was that small rodent abundance and consequently the role played by the whole rodent community as seed predator consistently varied across months and years. Other Oryzomys species, however, may present a different pattern of fruit/ seed consumption. To give one example, $O$. russatus was recorded to feed preferentially on pulp and small seeds ( $<15 \mathrm{~mm}$ length), and it left large seeds intact in a fragment of the Atlantic forest (Vieira et al., 2003).

The findings described above are consistent with the notion that over long periods, small rodents are able to play a detectable role on seed predation, demography and long-term persistence of small-seeded trees in both continuous (DeMattia et al., 2004; 2006) and fragmented landscapes (see Dirzo and Mendoza, 2007). More recent evidence, including our findings, suggests that seed predation by small rodents may be important for largeseeded trees as well. Habitat use, feeding behaviour and long-term demography of small rodents may thus impose ecological filters for tree species recruitment and largely determine safe sites for particular groups of species such large-seeded trees. Although seeds must be discarded far from parental plants in order to face reduced seed predation and increased recruitment (Janzen-Connell model), we have just found that seeds discarded beneath any fruiting tree (including non parental or co-specific individuals) face higher chances of being predated by generalists such as $O$. oniscus, particularly at the forest edge. There is large body of empirical evidence supporting the notion that food search by rodents is targeted on highresource spots. Peres et al. (1997) argued that differential rates of Brazil-nut seed removal by agoutis is driven by a cognition-based foraging effort focused on reproductive trees. It is reasonable to predict that small rodents, such as Oryzomys species, with their small home ranges may temporally reside around fruiting trees, and consequently predate opportunistically a large array of large-seeds dropped on the ground. This behaviour may be particularly impacting on forest edges since this habitat is be- 
lieved to produce (autochthonous seed rain) and receive (allochthonous seed rain) a small supply of large-seeds (Melo et al., 2006). In the Coimbra forest, adult trees without fruits appear to constitute low resource spots and provide, at least temporarily, safe sites for large-seeded trees.

In synthesis, the role played by small rodents as ecological filters for tree establishment is an emerging theme in the ecology of tropical modified landscapes, and remains largely controversial. According to DeMattia et al. (2004), as tropical forests become increasingly fragmented, the negative interactions between small rodents and seeds tend to drive seedling recruitment, tree species persistence and, consequently, the nature of tree assemblages. The Atlantic forest of northeast Brazil is now reduced to less than $6 \%$ of its original cover and the remaining forest is largely composed of small fragments (Ranta et al., 1998). Silva and Tabarelli (2000) predicted that over one third of large-seeded trees would face extinction in this region due to lack of effective seed dispersal. Would seed-predation by rodents represent an additional threat? Further studies must address the generality of the patterns described here and properly investigate possible impacts on demography of large-seeded trees resulting from small rodent seed predation in the fragmented landscapes of the Atlantic forest.

Acknowledgements - $\mathrm{CNPq}$ (Conselho Nacional de Desenvolvimento Científico e Tecnológico, Brasil) and Conservação Internacional do Brasil supported this study. Thanks to A. Langguth for rodent specimen identification, and to Mr. Heleno, an authentic field man, for the help with plant species identification and for his kindly presence. Two anonymous reviewers offered useful criticisms on the manuscript.

\section{References}

ADLER, GH., 1995. Fruit and seed exploitation by Central American spiny rats, Proechimys semispinosus. Stud. Neotrop. Fauna and Environment, vol. 30, no. 5, p. 237-234.

ASQUITH, N., WRIGHT, S. and CLAUSS, M., 1997. Does mammal community composition control recruitment in neotropical forests?. Evidence from Panama. Ecology, vol. 78, no. 2, p. 941-946.

BERGALLO, HG. and MAGNUSSON, WE., 2002. Effects of weather and food availability on the condition and growth of two species of rodents is Southeastern Brazil. Mammalia, vol. 66 , no. 1 , p. 17-31.

BRIANI, DC., VIEIRA, EM. and VIEIRA, MV., 2001. Nests and nesting sites of Brazilian forest rodents (Nectomys squamipes and Oryzomys intermedius) as revealed by a spool-and-line device. Acta Theriologica, vol. 46, no. 3, p. 331-334.

CINTRA, R. and HORNA, V., 1997. Seed and seedling survival of the palm Astrocaryum murumuru and the legume Dipteryx micrantha in gaps in Amazonian forest. Journal of Tropical Ecology, vol. 13, no. 1, p. 257-277.

CONNELL, JH., 1971. On the role of natural enemies in preventing competitive exclusion in some marine animals and rain forest trees. In DEN-BOER, PJ., GRADWELL, GR. (Ed.). Dynamics of populations. Wageningen: Centre for Agricultural Publications and Documentation. p. 298-312.

CORLETT, RT. and TURNER, IM., 1997. Long-term survival in tropical forest remnants in Singapure and Hong Kong. In LAURENCE, WF., BIERREGAARD JUNIOR, RO. (Ed.). Tropical forest remnants: ecology, management, and conservation of fragmented communities. Chicago: University of Chicago Press. p. 333-346.

DEMATTIA, EA., CURRAN, LM. and RATHCKE, BJ., 2004. Effects of small rodents and large mammals on neotropical seeds. Ecology, vol. 85, no. 8, p. 2161-2170.

DEMATTIA, EA., RATHCKE, BJ., CURRAN, LM., AGUILAR, R. and VARGAS, O. 2006. Effects of small rodent and large mammals exclusion on seedling recruitment in Costa Rica. Biotropica, vol. 38, no. 2, p. 196-202.

DIRZO, R. and MENDONZA, E. 2007, Size-related differential seed predation in a heavily defaunated neotropical rain forest. Biotropica, vol. 39, no. 3, p. 355-362.

EISENBERG, JF. and REDFORD, KH., 1999. Mammals of the neotropics: the central neotropics. Chicago: The University of Chicago Press. 609 p.

FERNANDES, ACA., 2003. Censo de mamíferos em alguns remanescentes de floresta Atlântica no nordeste do Brasil. Recife: Universidade Federal de Pernambuco. [Dissertação de Mestrado].

FLEURY, M. and GALETTI, M., 2006. Forest fragment size and microhabitat effects on palm seed predation. Biological Conservation, vol. 131, no. 1, p. 1-13.

FORGET, PM., 1990. Seed-dispersal of Vouacapoua americana (Caesalpinaceae) by caviomorph rodents in Franch Guiana. Journal of Tropical Ecology, vol. 6, no. 4, p. 459-468.

FORGET, PM. and JANZEN, PA., 2007. Hunting increases dispersal limitation in the tree Carapa procera, a nontimber forest product. Biological Conservation, vol. 21, no. 1, p. 106-113.

FRAGOSO, JMV., 1998. White-lipped peccaries and palms on the Ilha de Maracá. In MILLIKEN, W. and RATTER, A. (Ed.). Maracá: the biodiversity and environment of an Amazonian rainforest. New York: John Wiley and Sons. p. 151-164.

GALETTI, M., DONATTI, CI., PIRES, AS., GUIMARÃES, PR. and JORDANO, P., 2006. Seed survival and dispersal of an endemic Atlantic forest palm: the combined effects of defaunation and forest fragmentation. Botanical Journal of the Linnean Society, vol. 151, no. 1, p. 141-149.

GRELLE, CEV., 2003. Forest structure and vertical stratification of small mammals in a secondary Atlantic forest, Southeastern Brazil. Stud. Neotrop. Fauna and Environment, vol. 38, no. 2, p. 81-85.

GRILLO, AS., OLIVEIRA, MA. and TABARELLI, M., 2006. Árvores. In PÔRTO, C., ALMEIDA-CORTEZ, JS., TABARELLI, M. (Ed.). Diversidade biológica e conservação da floresta Atlântica ao norte do Rio São Francisco. Brasília: Editora Universitária-UFPE. p. 191-216. Série Biodiversidade no. 14 .

GUIMARÃES JUNIOR, PR., LOPES, PFM., LYRA, ML. and MURIEL, AP., 2005. Fleshy pulp enhances the location of Syagrus romanzoffiana (Arecaceae) fruits by seed-dispersing 
rodents in an Atlantic forest is south-eastern Brazil. Journal of Tropical Ecology, vol. 21, no. 1, p. 109-112.

HARPER, JL., 1994. Population biology of plants. New York: Academic Press. 892 p.

HENDERSON, A., 2002. Evolution and ecology of palms. New York: The New York Botanical Garden Press. 388 p.

HENRY, O., 1997. The influence of sex and reproductive state on diet preference in four terrestrial mammals of the French Guianan rain forest. Canadian Journal of Zoology, vol. 75, no. 6 , p. 929-935.

HOCH, GA. and ADLER, GH., 1997. Removal of black palm (Astrcaryum standleyanum) seeds by spiny rats (Proechimys semispinosus). Journal of Tropical Ecology, vol. 13, no. 1, p. $51-58$.

HOWE, HF. and SMALLWOOD, J., 1982. Ecology of seed dispersal. Annual Review of Ecology and Systematics vol. 13, p. 201-228.

Instituto Brasileiro de Geografia e Estatística - IBGE., 1985. Atlas Nacional do Brasil: Região Nordeste. Rio de Janeiro: IBGE. 1950-1968.

JANZEN, DH., 1970. Herbivores and the number of tree species in tropical forest. The American Naturalist, vol. 104, no. 904, p. 501-528.

1971. Seed predation by animals. Annual Review of Ecology and Systematics, vol. 2, no. 26, p. 465-492.

JORDANO, P., GALETTI, M., PIZO, MA. and SILVA, WR., 2006. Ligando frugivoria e dispersão de sementes à biologia da conservação. In ROCHA, CFD., BERGALLO, HG., Van SLUYS, M. and ALVES, MAS. (Ed.). Biologia da conservação: essências. São Carlos: Rima. p. 411-458.

JORDANO, P., GARCIA, C., GODOY, JA. and GARCIACASTAÑO, JL., 2007. Differential contribution of frugivores to complex seed dispersal patterns. Proceedings of the National Academy of Sciences, vol. 104, no. 9, p. 3278-3282.

KILTIE, RA., 1981. Distribution of palm fruits on a rain forest floor: why white-lipped peccaries forage near objects? Biotropica, vol. 13, no. 2, p. 141-145.

LEVEY, DJ., SILVA, WR. and GALETTI, M., 2002. Seed dispersal and frugivory: ecology, evolution and conservation. Oxford: CABI International. $536 \mathrm{p}$.

LOPEZ, L. and TERBORGH, J., 2007. Seed predation and seedling herbivory as factors in tree recruitment failure on predator-free forested islands. Journal of Tropical Ecology, vol. 23 , no. 2, p. 129-137.

MANGAN, SA. and ADLER, GH., 2000. Consuption of arbuscular mycorrhizal fungi by terrestrial and arboreal small mammals in a Panamanian cloud forest. Mammalia, vol. 81, no. 2 , p. $563-570$.

MELO, FPL., DIRZO, R. and TABARELLI, M., 2006. Biased seed rain in forest edges: evidence from the Brazilian Atlantic forest. Biological Conservation, vol. 132, no. 1, p. 50-60.

NUÑEZ-ITURRI, G. and HOWE, HF., 2007. Bushmeat and the fate of trees with seeds dispersed by large primates in a lowland rain forest in Western Amazonia. Biotropica, vol. 39, no. 3, p. $348-354$.
OLIVEIRA, FF. and LANGGUTH, A., 2004. Pequenos mamíferos (Didelphimorphia e Rodentia) de Paraíba e Pernambuco. Revista Nordestina de Biologia, vol. 18, no. 8, p. 19-86.

PERES, CA., SCHIESARI, LC. and DIAS-LEME, CL., 1997. Vertebrate predation of Brazil-nut, an agouti-dispersed Amazonian seed crop (Bertholletia excelsa, Lecythidaceae): a test of the escape hypothesis. Journal of Tropical Ecology, vol. 13 , no. 1 , p. $69-79$.

PIMENTEL, DS. and TABARELLI, M., 2004. Seed dispersal of the palm Attalea oleifera in a remnant of the Brazilian Atlantic forest. Biotropica, vol. 36, no. 1, p. 74-84.

PÔRTO, C., ALMEIDA-CORTEZ, JS. and TABARELLI, M., 2006. Diversidade biológica e conservação da floresta Atlântica ao norte do Rio São Francisco. Brasília: Ministério do Meio Ambiente. 363 p. Série Biodiversidade no. 14.

RANTA, P., BLOM, T., NIEMELÃ, J., JOENSUU, E. and SIITONEN, M., 1998. The fragmented Atlantic forest of Brazil: size, shape and distribution of forest fragments. Biodiversity and Conservation, vol. 7, no. 3, p. 385-403.

REDFORD, KH., 1992. The empty forest. Bioscience, vol. 42, no. 6, p. 412-422.

REIS, A., 1995. Dispersão de sementes de Euterpe edulis Martius (Palmae) em uma floresta ombrófila densa montana de encosta Atlântica em Blumenau. Campinas: UNICAMP. [Dissertação de Mestrado].

RICHARDS, PW., 1996. The tropical rain forest. Cambridge: Cambridge University Press. 574 p.

SANTOS, BA., PERES, CA., OLIVEIRA, MA., GRILLO, A., ALVES-COSTA, CP. and TABARELLI, M., 2008. Drastic erosion in functional attributes of tree assemblages in Atlantic forest fragments of northeastern Brazil. Biodiversity and Conservation. No prelo.

SILVA, GM. and TABARELLI, M., 2001. Seed dispersal, plant recruitment and spatial distribution of Bactris acanthocarpa Martius (Arecaceae) in a remnant of Atlantic Forest in northeast Brazil. Acta Oecologica, vol. 22, no. 5-6, p. 259-268.

2000. Tree species impoverishment and the future flora of the Atlantic forest of northeast Brazil. Nature, vol. 404, no. 6773 , p. $72-74$.

SMYTHE, N., 1989. Seed survival in the palm Astrocaryum standleiuanum: evidence for dependence upon its seed dispersers. Biotropica, vol. 21, no. 1, p. 50-56.

SOKAL, RR. and ROHLF, FJ., 1995. Biometry. New York: WH. Freeman and Company. 859 p.

TABARELLI, M. and PERES, CA., 2002. Abiotic and vertebrate seed dispersal in the Brazilian Atlantic forest: implications for forest regeneration. Biodiversity and Conservation, vol. 106, no. 2, p. 165-176.

TALAMONI, SA. and DIAS, MM., 1999. Population and community ecology of small mammals in southeastern Brazil. Mammalia, vol. 63, no. 2, p. 167-181.

TERBORGH, J., 1990. Seed and fruit dispersal commentary. In BAWA, KS. and HADLEY, M. (Ed.). Reproductive ecology of tropical forest plants. Paris: UNESCO and The Parthenon Publishing Group. p. 181-190. 
TERBORGH J., LOPEZ L., NUNEZ P., RAO M., SHAHABUDDIN G., ORIHUELA G., RIVEROS M., ASCANIO R., ADLER G.H., LAMBERT TD. and BALBAS L. 2001. Ecological meltdown in predator-free forest fragments. Science, vol. 294, no. 5548, p. 1923-1925.

TERBORGH, J. and NUÑEZ-ITURRI, G. 2006. Disperser-free tropical forests await an unhappy fate. In LAURANCE, WF. and PERES, CA. (Ed.). Emerging threats to tropical forests. Chicago: The University of Chicago Press. p. 241-252.

TURNER, IM., 2001. The ecology of trees in the tropical rain forest. Cambridge: Cambridge University Press. 312 p.

VELOSO, HP., RANGEL-FILHO, ALR. and LIMA, JCA., 1991. Classificação da vegetação brasileira adaptada a um sistema universal. Rio de Janeiro: IBGE. 82 p.

VIEIRA, EM., PIZO, MA. and IZAR, P., 2003. Fruit and seed exploitation by small rodents of the Brazilian Atlantic forest. Mammalia, vol. 67, no. 4, p. 533-539.

WHITMORE, TC. 1991. An introduction to tropical rain forests. Oxford: Clarendon Press. 226 p.
1996. A review of some aspects of tropical rain forest seedling ecology with suggestions for further enquiry. In SWAINE, MD. (Ed.). The ecology of tropical tree seedlings. Paris: UNESCO and the Parthenon Publishing Group. p. 3-40.

WILSON, DE. and JANZEN, DH., 1972. Predation on Scheelea palm seeds by bruchid beetles: seed density and distance from the parental palm. Ecology, vol. 5, no. 53, p. 954-959.

WRIGHT, SJ., 2003. The myriad consequences of hunting for vertebrates and plants in tropical forests. Perspectives in Plant Ecology Evolution and Systematics, vol. 6, no. 1-2, p. 73-86.

WRIGHT, SJ. and DUBER, HC., 2001. Poachers and forest fragmentation alter seed dispersal, seed survival, and seedling recruitment in the palm Attalea butyracea, with implications for tropical tree diversity. Biotropica, vol. 33, no. 4, p. 583-595.

WRIGHT, SJ., HERNANDÉZ, A. and CONDIT, R., 2007. The bushmeat harvest alters seedling banks by favoring lianas, large seeds, and seeds dispersed by bats, birds, and wind. Biotropica, vol. 39 , no. 3, p. 363-371. 